\title{
The Role of The Town Planning Department towards Development and Socio-Economics in Kinta Valley, 1921- 1941
}

Khairi Ariffin, Mohd Hairy Ibrahim, Mohd Kamal Kamaruddin, Sahul Hamid Mohamed Maiddin, Wan Norlizawati Wan Mat Ali, Siti Zaharah Mahfood, Tuan Waheda Tuan Chik

To Link this Article: http://dx.doi.org/10.6007/IJARBSS/v11-i10/11514

DOI:10.6007/IJARBSS/v11-i10/11514

Received: 11 August 2021, Revised: 09 September 2021, Accepted: 28 September 2021

Published Online: 15 October 2021

In-Text Citation:(Ariffin et al., 2021)

To Cite this Article: Ariffin, K., Ibrahim, M. H., Kamaruddin, M. K., Maiddin, S. H. M., Ali, W. N. W. M., Mahfood, S. Z., \& Chik, T. W. T. (2021). The Role of The Town Planning Department towards Development and SocioEconomics in Kinta Valley, 1921-1941. International Journal of Academic Research in Business and Social Sciences, 11(10), $1326-1333$.

\section{Copyright: (c) 2021 The Author(s)}

Published by Human Resource Management Academic Research Society (www.hrmars.com) This article is published under the Creative Commons Attribution (CC BY 4.0) license. Anyone may reproduce, distribute, translate and create derivative works of this article (for both commercial and non-commercial purposes), subject to full attribution to the original publication and authors. The full terms of this license may be seen at: http://creativecommons.org/licences/by/4.0/legalcode

Vol. 11, No. 10, 2021, Pg. $1326-1333$ 


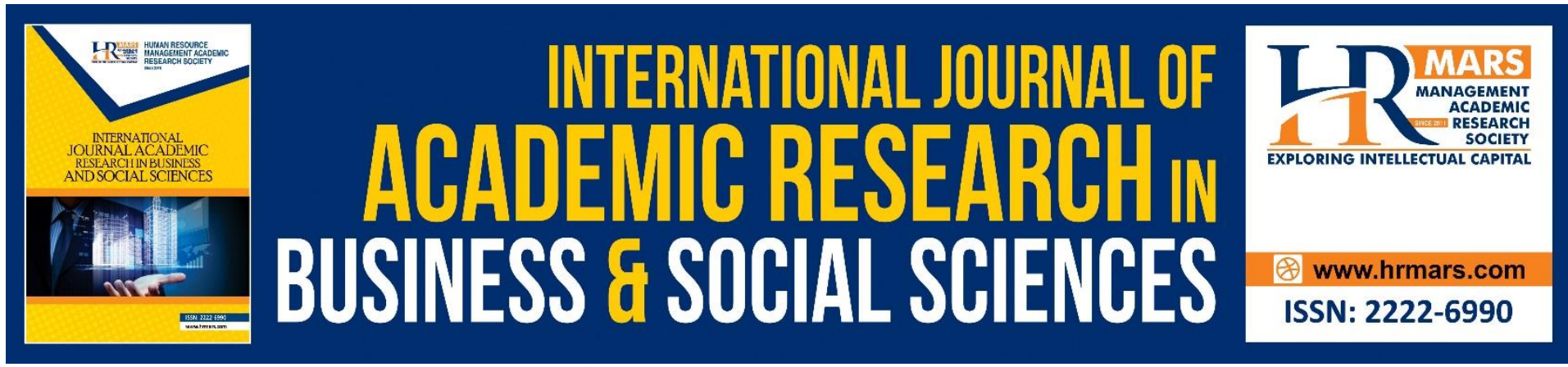

\title{
The Role of The Town Planning Department towards Development and Socio-Economics in Kinta Valley, 1921-1941
}

\author{
Khairi Ariffin ${ }^{1}$, Mohd Hairy lbrahim², Mohd Kamal Kamaruddin ${ }^{3}$, \\ Sahul Hamid Mohamed Maiddin ${ }^{4}$, Wan Norlizawati Wan Mat \\ Ali $^{5}$, Siti Zaharah Mahfood ${ }^{6}$, Tuan Waheda Tuan Chik ${ }^{7}$ \\ ${ }^{1 \& 2}$ Assoc. Prof, Faculty of Human Science, Universiti Pendidikan Sultan Idris, Perak, Malaysia, \\ 3,4,5 \&6 Senior Lecturer Faculty, of Human Science, Universiti Pendidikan Sultan Idris, Perak, \\ Malaysia, ${ }^{7}$ Postgraduated, Faculty of Human Science, Universiti Pendidikan Sultan Idris, \\ Perak, Malaysia
}

\begin{abstract}
This study is about the role implemented by the Town Planning Department on socioeconomic development and development in the Kinta Valley district. The Kinta valley area is a rapidly developing area with socio-economic activities of agriculture and tin mining. The Lembah Kinta district town planning department is directly involved in the development plan of Ipoh town and the small towns in the Kinta Valley district because the town and small towns are the catalyst for the development and socio-economic activities of the community. Having been founded in 1921, the British colonial administration created a new organization with the existence of the involvement of British officials and the local community in management and administration. This study was conducted using a qualitative method that is to analyze documents and manuscripts on documents obtained from the National Archives of Malaysia and public university libraries in Malaysia. The results show that various development plans and implementations have been carried out by the Town Planning Department in the Kinta Valley district. Aspects implemented are the construction of settlements, infrastructure facilities such as communication networks and also the construction of new buildings. In fact, the Town Planning Enactment was also introduced to overcome the problem of ownership of homes and business premises in the cities around the Kinta Valley. In conclusion, this study proves that the Town Planning Department had a tremendous contribution to the socioeconomic development and urban development in the Kinta Valley district in the British colonial era.
\end{abstract}

Keywords: Town Planner, Socio-Economics, Development, British Officials, Enactment

\section{Introduction}

In the era of British colonial administration, Hilir Perak district was a very important district in its role as a port center and agricultural activities and the Kinta Valley district was considered as to the economic development of tin mining. Socio-economic and development activities 
are the most important which is a shift to economic development in the Kinta Valley is referring to the influence and role involving the department of Planning and urban development. The Town Planning Department or known as the Town Planning Department was officially established in 1921. The Town Planning Department is basically responsible for all urban development planning matters that contribute directly to socio-economic development.

The history of early planning regarding urban development began with the Kinta Sanitary Board founded in 1893 by Frank Swettenham which initially aimed to tackle the problem of crime and congestion that occurred in the city. Prior to the establishment of the Town Planning Department, the implementation work in the development of communication infrastructure and urban development was under the responsibility of the Public Works Department. After that, the field of management has been further developed with the introduction of the Town Planning Department. After the establishment of the Town Planning Department, all planning and management work is more organized in addition to the introduction of new committee members in the department. In fact, throughout the colonial administration in the state of Perak, these three departments are still closely related to each other in every planning and implementation of urban development, especially in the Kinta Valley.

\section{Research Problems}

The British administration in the state of Perak was strengthened with the introduction of departments responsible for economic and administrative management in the state of Perak. The formal establishment of the Federal Town Planning Department in 1911 has been a catalyst for more systematic urban development in the Kinta Valley. The Kinta Valley district is also considered as the most important district in contributing to socio-economic activities and urban development due to the development and socio-economic planning plans carried out by the Town Planning Department which is staffed by administrative officers among the British and locals.

\section{Literature Review}

Research reviews are important in the early stages of research that provide a similar picture of the overall research as well as the findings of previous studies (Nasution \& Lubis, 2005) Most of the previous studies are on the history of the development of the tin ore industry in Perak during the British colonial era and its impact on urban development in the state of Perak. Urbanization in a place occurs due to economic activities carried out by the community in a place.

According to Tate (1970) in his writing 'The Making Of Modern South East Asia', it was focused on the modernization and establishment of cities in countries in Southeast Asia, including Malaya. The writing is focused on activities and factors that led to the development of the city in Malaya consisting of local economic activities carried out during the British colonial era. Urban planning organizations play an important role in other to structure the urban development. Nasution and Lubis (2005) also emphasized that the development structured by the colonial was took place in major cities and focused on the Kinta Valley district. This writing gives the impression that there is a role that has been implemented by the Town Planning Department in ensuring a planned and organized urban development in the Kinta Valley (Tate, 1979). 
According to Ooi in Land, People and Economy in Malaya, Kinta Valley has a high population density due to the tin mining activities (Nasution \& Lubis, 2005) The increasing population density mainly due to the influx of Chinese and Indian immigrants has further accelerated the process of urbanization in the Kinta Valley. Ooi Jin Bee's study has illustrated that the role and involvement of the Town Planning Department in the Kinta Valley was very important in ensuring the settlement of residents in the Kinta Valley area is structure in more organized way and focused on the high potential areas for economic activities in the cities. Apart from that, Mohd Razali Agus also highlighted that the development of the city in Malaya is due to the colonial success in dominated the political and socioeconomic aspects but did not clearly focus on the administration of urban management by the colonial government (Ooi, 1961). Both of these writings give the impression that the good administrators in socioeconomic and political aspects is very important in implemented the urban planning.

In addition, Gullick (2012), also emphasizes in his writing that town planning institutions have assisted in a form of development control as well as zoning over land use. The Kinta Valley is also noted as a pioneer of large scale development as it started from a village and transformed as a city with the population of 13,000 peoples in 1879 . This study shows that the Kinta Valley is a district which experienced the urban development since the end of the 19th century.

The study of population in urban settlement development was also emphasized by Yaakob et al (2010). The urban development in 1911 was considered as one of the important policies in British colonial administration but there are no specific findings regarding the policy as well as the organization of organizations responsible for the policy. The evolution of urban development in Ipoh is also stated in Shahidin (2017) study which focuses on three aspects that contribute to urban development in Ipoh which involves administration, economy and social. This study helps in providing an overview of the urbanization process that occurs in Ipoh as well as the involvement of the Town Planning Department in the process of urban formation in Ipoh and the Kinta Valley in particular.

Mamat and Aziz (2018), in their study emphasized that the grid system that had been introduced by the British colonial government had showed the impact on the layout of the earliest cities such as Ipoh and Taiping. However, this study does not describe the role of the Town Planning Department in the implementation of the urbanization process in the Kinta Valley. Overall, the study helps in briefly identifying the role that has been carried out by the Town Planning Department in the work of town planning in the state of Perak in general.

\section{Research Methodology}

The study was conducted using a qualitative method that emphasizes the analysis of official colonial manuscripts and documents. Primary document sources are obtained from the National Archives of Malaysia department and public educational institutions such as the University of Malaya library, Universiti Kebangsaan Malaysia library, and National Library of Malaysia. Among them are the Perak Government Gazette, Perak Secretariat and also the Federated Malay States Annual Report obtained from the National Archives of Malaysia. In addition, secondary reference is also made as observing the books and writings related to economic development and cities in Perak and the Federated States showing the influence and the British colonial administration in the Malay states. 


\section{Findings}

The British colonial administration in the state of Perak gave great priority and attention to the process of urban development. After the British colonial entry and intervention in the administration, the colonialists had suggested that there was a need to make a change to the condition of the existing building premises at the focus locations in Perak especially the Kinta Valley (Gullick, 2012). Since the urban development is essential for the economic development of the state, various schemes, enactments and even new organizations have been created to ensure an organized urban administration. The increasingly stable urban development in the 1920s also led to the strengthening of the role of the Town Planning Department through the implementation of policies and programs carried out in the major cities of Perak, especially in the Kinta Valley.

The Kinta Valley is categorized as a pioneer of development in the state of Perak. The Kinta Valley consists of sixteen towns (Perak Secretariat 3277/1948) and the main cities was Ipoh, Gopeng, Batu Gajah, Papan, Lahat and Dipang. There were large number of settlements as well as brick based buildings and became the main settlements of the miners. This is one of the benchmarks to the development of a city during the beginning of the British colonial administration in the state of Perak in the late 19th century. In 1884, the Kinta district headquarters was moved from Kota Bharu to Sungai Terap in Batu Gajah since it was considered as the best area for the construction of houses (Annual Report on The State of Perak, 1884).

The Town Planning Department played an important role especially during the election of the city of Ipoh as the official capital of Perak in 1927 (Annual Report On The State Of Perak, 1884). In 1927, Ipoh replaced the city of Taiping as the capital of Perak. The selection of Ipoh as the capital of Perak was due to several factors such as the city's reputation which was declared as the cleanest city. In addition, the arrangement of the city of Ipoh was considered very well organized as cities from European countries. This was due to the fact that the expertise of British civil engineers had been used in the administration.

The town planning enactment especially in the Kinta Valley area was drafted by the Government Town Planner. The scope and limitations of this enactment involve the matters that related to the development of new areas, planning and upgrading of existing areas, housing and also settlements. The work and task involving the Town Planning Department in the Kinta Valley was rising during 1920s (Fourth Annual Report of Government Town Planner, 1925). One of the most important works that were implemented around the 1920 s were the adjustment of railways line as well as the widening of major roads. Until the end of 1924, the department need the high cost to carry out the work in the Kinta Valley area. The department was received a large allocation from the state government. The total emoluments of staff and officers in the department is one of the largest allocations at $\$ 48,706.00$. The staff involved includes subordinate staff who carry out clerical work. The printing and drawing materials of the plan cost $\$ 1335.00$ (Fourth Annual Report of Government Town Planner, 1925). All records of expenditure and allocations received are carefully recorded and recorded in the annual report of the Town Planning Department.

In Town Planning Department, there were rules regarding the appointment of the committee members in the administration. The members of this commitee or called members of the town planning government, (Government Town Planner) for the Kinta Valley district consists of administrative officers as well as professional officers. The committee members were leaded by the chairman of the Kinta Sanitary Board and the vice chairman of the town planning officer. The other members involved consisted of state engineers and deputy 
superintendents of state revenue procurement surveyers (Fourth Annual Report of Government Town Planner, 1925). All administrative officers and professionals appointed in 1924 were British officers.

In 1927, a new level of development was recorded throughout the early establishment of the Town Planning Department (Selangor Secretariat 8b5/1928). This is due to the increament of land ownership applications as well as requests for the purchase of building premises. Works and housing projects under the responsibility of the government were also intensified starting in 1927 due to high demand from foreign and local investors. The high numbers of Chinese and Indians labour especially in Ipoh, also affected the number of the urban population. The increase in population that took place by the end of the 1920s had led to the problem of lack of housing areas. Existing residential premises built in Ipoh in the late 1920s could not meet the demand for housing ownership.

By the 1930s, great progress had been recorded in the Kinta Valley according to the plan set by the Town Planning Department. Among the development in 1930s was the construction of low-cost shophouses in Kuala Kangsar Road, Ipoh (Town Planning Department Annual Report, 1939). The main purpose of the low cost shop house was to provide safe and suitable business premises for economic activities. Low cost housing settlements were also bulit in Gopeng to replace the old settlements on the roadside known as Kopisan Tekka. The increase in population due to the development of inter-urban connectivity in the Kinta Valley has also affected the emergence of markets that provide food supplies (Sadka, 1968). The existence of this market give space to the farmers have the place in urban areas to sell their surplus crops. This situation showed that urban development as planned by the Town Planning Department has affected the economy and increase the community revenue since the had the opportunities to conduct business activities more widely.

Around the 1930s as well, the Town Planning Department came down to plan an entertainment-themed business area in Ashby Road, Ipoh (Town Planning Department Annual Report, 1939). The development plan on Ashbey Road has been known as a fair-park. Apart from Ashbey Road, the development of this fair-park themed area was also implemented in Maxwell Road and Pasir Puteh. In fact, the construction of entertainment venues such as cinemas was also erected on Brewster Road and Chamberlain Road. The construction of the cinema was approved by the Town Planning Committee which takes into account several important aspects in the construction such as the design of the interior and exterior of the building premises. Parking facilities in the area of the business premises are also taken into account to avoid the traffic problems.

In other to overcome the problems faced, the Town Planning Department was implemented the operation of the new Town Planning Enactment throughout the state of Perak. The development planned and carried out had been focusing in Ipoh town. Among the operations carried out in the Town Planning Enactment in Perak are as shown in the table below. 
Table 1: Work done by the Town Planning Department 1927

\begin{tabular}{l|l}
\hline Work done & Total application and construction \\
\hline Private building construction plan & 326 \\
Private sub-divisions & 46 \\
Mining lease & 1 \\
Government building & 9 \\
Government land application & 2 \\
Public administration & 60 \\
\hline Total & 489 \\
\hline
\end{tabular}

Source: Selangor Secretariat 8b5/1928, Annual Report 1927, Town Planning Department Federated Malay States.

Table 1 shows the planning and work carried out under the responsibility of the Town Planning Department. Based on the schedule, the construction of private buildings is the most implemented in the state of Perak and followed by private-sub divisions. Mining lease applications received from the Town Planning Department in 1927 were the fewest with only one lease application.

After the proclamation of Ipoh as the state capital of Perak, the Town Planning Department has implemented The Perak Town Planning Exhibition program and exhibition to disseminate information to the public on urban development in the Kinta Valley since the era of British colonialism in Perak (Selangor Secretariat 8b5/1928). The exhibition was held at Ipoh Town Hall in 1928 and was implemented in the form of an exhibition of poster illustrations, pictures and even plans. The exhibition, organized by the Town Planning Department, was the first to be held since the establishment of the organization. The exhibition program shows that there was a direct two -way approach between the administration and the people and at the same time to provide an understanding on the implementation of administration in the colonial government. It is important for the people, especially the urban residents involved, to understand and know about the development history and implementation plan of the urban development.

\section{Conclusion}

The role of the Urban Development Department is very important in the planning and implementation of urban development in the Kinta Valley. The plans and developments implemented was affected the socioeconomic of the people due to the vast economic opportunities due to the increase in population. In addition, the involvement of professionals in the administration of the Town Planning Department such as engineers and architects from Europe had been one of the factors of more continuous urban development in the Kinta Valley during the British colonial era.

\section{Acknowledgement}

This study is under the provision of external research approved by Research Management \& Innovation Centre (RMIC) of Sultan Idris Education University. (Research Code: 2020-0028106-29). Special thanks and high appreciation to Sairi Jaya Enterprise on the support and sponsorship of a research grant. 


\section{References}

Agus, M. R. (1992). Proses Perbandaran dan Masyarakat Melayu Bandar, Pembangunan Perumahan: Isu dan Prospek, Kuala Lumpur:Dewan Bahasa dan Pustaka. Annual Report on the State Of Perak, 1884

Gullick, J. M. (2012). The Builders. Journal of Malaysian Branch of the Royal Asiatic Society, 85 (2), 79-98

Mamat, M. J., \& Aziz, M. F. A. (2018), Early Town Planning System of Small Towns in Perak. Journal of the Malaysian Institute of Planners. 16(4). 55-67

Nasution, K. S., \& Lubis, A. R. (2005). Kinta Valley Pioneering Malaysia's Modern Development. Ipoh: Perak Academy.

Ooi, J. B. (1961). Land, People and Economy in Malaya. London: Longman, Green \& Co Ltd. Perak Secretariat 3277/1948, Name of Town and Village in Perak.

Sadka, E. (1968). The Protected Malay States. Kuala Lumpur: University of Malaya Press. Selangor Secretariat 8b5/1928, Annual Report 1927, Town Planning Department Federated Malay States

Shahidin, A. A. (2017). Evolusi Perbandaran Ipoh, Master thesis, Jabatan Sejarah, Fakulti Sastera dan Sains Sosial, Universiti Malaya. Supplement To Federated Malay Stated Government Gazette, Department of Town Planning, Fourth Annual Report of Government Town Planner 1925

Tate, D. J. M. (1979). The Making of Modern South-East Asia. Kuala Lumpur: Oxford University Press.

Tobi, S. U. M. (2014), Qualitative Research \& Nvivo 10 Exploration, Kuala Lumpur: Aras Publisher Town Planning Department Annual Report 1939.

Yaakob, U., Masron, T., \& Masami, F. (2010). Ninety Years of Urbanization in Malaysia: A Geographical Investigation of Its Trends and Characteristics, Journal Ritsumeikan Social Science Humanity, 4, 79-101 